\title{
PHYSICOCHEMICAL, FUNCTIONAL AND SENSORY PROPERTIES OF PROTEIN EXTRACTED FROM DESICCATED COCONUT
}

By

\author{
F. Rasyid and P. M. T. Hansen ${ }^{1}$
}

\begin{abstract}
Coconut protein (CNP) was extracted from desiccated coconut in $1.0 \mathrm{M}$ sodium chloride (1:15), precipitated by HCI, ultra filtered, and freeze-dried. The physicochemical, functional, and sensory characteristics of the material were compared with those of soy protein. The composition and chemical analyses included measurements of protein, fat, moisture, carbohydrate, ash, minerals, and amino acids. Other measurements included determination of die contents of sulfhydryl and disulfide groups, hydrophobicity values, and electrophoretic patterns of CNP and soy protein. The bulk density of the protein preparations was also measured. Chemical analyses showed that CNP was comparable in overall composition to the reference soy protein with the exception of high sodium content $(4.7 \%)$. Amino acid analysis revealed a higher content of arginine and a lower content of aspartic acid and lysine. A test for relatedness among, proteins ( $\Delta \Delta \mathrm{Q}$ ) showed very little similarity between the amino acid profiles of the two protein entities. CNP was found to be more hydrophobic than soy protein and contained slightly less sulthydryl and disulfide groups. The disparity in the above values was reflected in dissimilarity in the electrophoretic patterns between CNP and soy protein. CNP exhibited a lower solubility but possessed a similar water binding and a higher lipid absorption capacity than soy protein. Sensory evaluation using crackers prepared with different amounts of the two proteins showed that crackers with added CNP were preferred over crackers with added soy protein. The overall results of this study suggest a potential use of CNP as an alternative protein source to soy protein for use in manufactured foods where solubility is not a critical factor.
\end{abstract}

\section{INTRODUCTION}

Coconut (Cocos nucifera) is considered one of the useful crops in many of the tropical countries such as Indonesia, the Philippines, India, Sri Lanka, Thailand, Malaysia, West Africa and Oceania. This crop has been harvested for thousand of years and has been utilized to support the life of millions of farmers and their families. In addition, coconut and its products have become part of the growing agricultural business and industry that contribute to the gross national product of these countries in modem times. Therefore, there is no doubt that coconut and its industries will continue to play an important role in the economic and domestic life of the people in these areas of the World.

On the other hand, the coconut-producing countries face the dilemma of decreasing world price of coconut oil that is the most valuable product of coconut. The trend of the oil price has been in a decline for the past forty years and it has been estimated that the price will be even lower in the future (1). Recently, the dilemma has become more acute due rigorous and strong competition from other vegetable oils, such as soybean, rapeseed, and corn oil. The competition has become more severe because of a mounting campaign in the western world against "tropical oils". As a consequence of this campaign, many food producers in the west have replaced coconut oil in their manufactured foods and many products are now labeled with the words: "Contains no Coconut or Palm Oil". This directly results in lowering the income of coconut farmers and indirectly reduces the value of coconut. Thus, it appears that coconut-producing countries can no longer rely on coconut oil as the main product but must diversify into other products by utilizing the components of coconut, such as protein and carbohydrate, which could add value to coconuts.

${ }^{1}$ The Agency for Assessment and Application of Technology of Indonesia (BPP Teknologi) and Department of Food Science and Technology, The Ohio State University, Columbus, Ohio 43210, USA, respectively. 
Coconut meat (kernel) is commonly processed for the recovery of its oil using copra as starting, material. The residual meal contains - 20 protein (2) but traditional processing methods render it generally unfit for human consumption. One possible way to increase the added value of the coconut harvest is to improve the prospect for utilization of its protein. With recent development of several wet processing methods, a recovery scheme is possible for a food grade protein. Even thought the protein content of coconut meat is low $(4 \%)$, the large crop grown could make the recovery of the protein economically attractive. An estimated 1.7 million tons of protein from fresh coconut or 0.5 million tons from copra on a world-wide basis is potentially available for human consumption (3).

With increased attention to improving coconut processing technology, the future utilization of coconut protein could become a reality for some developing countries where there are high incidences of protein malnutrition and unaffordable price of animal protein. Additionally, the use of coconut protein for human consumption provides an attractive benefit compared to the commonly available soy protein which is characterized by an unacceptably beany flavor. Coconut protein has inherently a pleasant taste and exhibits flavor properties which are generally acceptable to most people (2).

Coconut proteins have been shown to possess a favorable amino acid profile and for this reason are considered to be of a fairly high nutritional value (2). So far, published information on coconut protein is rare and only a few studies have been carried out to support the utilization of coconut proteins. This research was undertaken to analyze the chemical, functional, and sensory properties of protein extracted from desiccated coconut.

\section{MATERIAL AND METHODS}

\section{PROTEIN PREPARATION}

Desiccated coconut (DCN) used in this experiment was procured from a local supermarket and was originally imported from The People's Republic of China by Hip Sang Cheung Yee Kee, Hong Kong. Coconut protein (CNP) was extracted using salt solution. Precipitated by acid, and purified using, ultra filtration, as described in Figure 1 and 2 (4). Soy protein concentrates were donated by CENTRAL SOYA, Chemurgy Division, Fort Wayne, Indiana.

\section{COMPOSITION AND CHEMICAL ANALYSES}

Protein, fat, moisture and ash content of CNP were determined using the standard procedures by A. O. A. C. (5). A conversion factor of 5.3 was used to calculate the total protein content as recommended by A. 0. A. C. (5). Mineral was, determined by argon plasma spectrometry at the Research Extension Analytical Laboratory (REAL) located at the Ohio Agricultural Research and Development Center (Wooster, Ohio).

Amino acid was conducted by the OSU Biochemical Instrument Center using high performance liquid chromatography (PICO.TAG-System Waters, Division of Millipore). Samples were treated by vapor phase hydrolysis at constant boiling with HCI for $24 \mathrm{hr}$ under nitrogen flush. The amino acids were derivatized with phenylthiocianate (PTC) prior to analyses. Tryptophan, methionine, and cysteine were not analyzed separately.

The hydrophobicity values of the samples were measured by a heptane binding method according to the modified method of Mohammadzadeh-k et al. (6) and Mangino et al. (7) and by cis-parinaric acid (CPA) according to the modified method of Kato and Nakai (8). The hydrophobicity value was also calculated in accordance with Bigelow's method (9). 
The sulfhydryl (SH) and disulfide (SS) content of protein samples were determined using Ellman's reagent (5,5'-dithiobis-2-nitrobenzoic acid) as described by Beveridge et al. (10). Absorbance was measured at $412 \mathrm{~nm}$ on a Perkin Elmer DB spectrophotometer, Model Coleman 124.

Sodium dodecyl sulfate-polyacrylamide gel electrophoresis (SDS-PAGE) was conducted by the method of Laemmli (11) using a $4-20 \%$ acrylamide linear gradient ready gel in a vertical Mini-PROTEAN 11 electrophoresis cell (Bio-Rad Laboratories, Richmond, CA). The protein samples including unfractionated protein from fresh coconut, CNP, and soy protein were subjected to electrophoretic analysis against a series of known protein standards (low molecular weight standard for SDS-PAGE, Bio-Rad Laboratories).

\section{PHYSICAL AND FUNCTIONAL EXAMINATION}

The physical and functional experiments consisted of a 30 factorial design with three levels of $\mathrm{pH}(5.0,6.5$, and 8.0$)$ and three levels of temperatures $\left(30,50\right.$, and $\left.70^{\circ} \mathrm{C}\right)$ for solubility and water binding, respectively. For lipid absorption, the following independent variables, protein concentrations $(5,10$, and $15 \%)$ and temperatures $\left(30,50\right.$, and $\left.70^{\circ} \mathrm{C}\right)$ were selected. Nine possible combinations of samples for each experiment with two replications were analyzed in this study.

A multiple regression analysis using the system for statistics designed for the Macintosh computer was used to derive an empirical equation for the prediction of protein solubility, water binding, and lipid absorption of CNP and soy protein (12). The empirical equation was applied to construct a 3D plot using the system for graphics designed for the Macintosh computer (13).

\section{SAMPLE PREPARATION}

Aliquots of protein samples $(5 \% \mathrm{w} / \mathrm{v})$ were dispersed in distilled water and $0.12 \mathrm{~g} \mathrm{Nacl} / \mathrm{g}$ dried sample was added to soy protein to adjust the sodium concentration to be equal to that of CNP. The dispersed samples were homogenized using a Polytron homogenizer (Brinkman Instruments) at speed setting 5 for $1 \mathrm{~min}$. The $\mathrm{pH}$ of the samples was adjusted, to $(5.0,6,5$, and 8.0) and mixed by a magnetic strirrer at specific temperatures $\left(30,50\right.$ and $\left.70^{\circ} \mathrm{C}\right)$ for $30 \mathrm{~min}$. After equilibration at room temperature, the sample; were centrifuged at $3,000 \mathrm{rpm}$ for $30 \mathrm{~min}$.

\section{SOLUBILITY}

Solubility was measured in terms of the protein solubility index in accordance with the method of Voutsinas et al. (14). Protein content in the suspension before centrifugation and the supernatant after centrifugation, as described in the sample preparation, was determined by a modified Bradford protein-dye binding assay (15). The percent solubility index was calculated as the ratio of the protein content of the supernatant to that of the suspension.

\section{WATER BINDING}

Water binding was determined in accordance with the modified method of Aguilera and Kosikowski (16). Following sample preparation, the supernatant was discarded. The excess water on the wall of the tubes was removed by wiping with Kimwipes-tissue. The tubes were reweighed. The water binding, (WB) was calculated as water absorbed in g water per gram of sample.

\section{LIPID ABSORPTION}

Lipid absorption was measured in accordance with the modified method of Lin et al. (1 7). Aliquots of 5.0. 10.0, and $15.0 \%$ protein samples were dispersed in mazola-corn oil and Q $12 \mathrm{~g}$ $\mathrm{NaCl} / \mathrm{g}$ dried sample was added to soy protein to adjust the sodium concentration to be equal to that 
of CNP. The dispersed samples were homogenized using a Polytron homogenizer at speed setting 5 for $1 \mathrm{~min}$. The solutions were mixed using a heated-magnetic stirrer at specific temperatures; $(30,50$, and $70^{\circ} \mathrm{C}$ ) for $30 \mathrm{~min}$. After equilibration at room temperature, the samples were filled into preweighed centrifuge tubes and centrifuged at 3,000 rpm for $30 \mathrm{~min}$. The free oil was discarded. The excess oil on the wall of the tubes was removed by wiping, with Kimwipes- tissue. The tubes were reweighed. The lipid absorption (LA) was expressed as oil absorbed in $g$ oil per $g$ of sample.

\section{BULK DENSITY}

Bulk density of was determined according to the method of Wang and Kinsella (18). Protein samples were placed in a $25 \mathrm{ml}$ graduated cylinder and packed by gently tapping the cylinder on the bench top 10 times from a height of $5 \mathrm{~cm}$. The weight and volume of the samples were recorded. The procedure was repeated three times for each sample and the bulk density was calculated as, $\mathrm{g} / \mathrm{ml}$ of the sample.

\section{SENSORY EVALUATION}

A flour matrix for crackers was prepared with a basic ratio of 1: 1 wheat flour and potato starch. The flour matrix was blended with $0.0,10,20,30$, and $40 \%$ CNP or soy protein concentrate. The dry blend was mixed with water of a varying ratio between 1.0: 0.8 and 1.0: 1.0. It was necessary to increase the amount of water added as the concentration of CNP increase in order to, produce suitable dough. To the soy protein mix was added $0.12 \mathrm{~g} \mathrm{NaCl}$ per gram of dried, sample to adjust the sodium concentration to that of CNP. The individual components; were combined in a mixing bowl and kneaded by hand for $5 \mathrm{~min}$ and then incubated for $30 \mathrm{~min}$. After incubation, the dough was rolled and cut into small squares $0 \times 1 \mathrm{~cm}$ ), and finally heated in a microwave oven for 4 min. The crackers were submitted for flavor and texture evaluation by a panel of 19 untrained observers using a rank preference test with 1 being the least preferred flavor or texture and 6 the most preferred flavor or texture (19).

\section{RESULTS AND DISCUSSION}

\section{COMPOSITIONAL AND CHEMICAL ANALYSES}

The gross composition of CNP and soy protein concentrate is shown in Table 1. In general, overall analyses show that CNP is comparable in composition with soy protein. Protein is the highest component of these products, which is above $64 \%$. CNP has a similar ratio of carbohydrate to protein (0.23) compared to soy protein $(0.28)$ and the fat content of both proteins are almost identical $(1 \%)$. The level of protein in CNP and the reference soy protein qualifies these products 'under the designation of protein concentrates. The contribution of proteins to, quality attributes of several major foods has been elucidated in several reports, (20,21, and 22). The physical behavior of protein is influenced by its amino acid composition, its molecular size, primary structure, the conformation of the protein, the charge distribution on the protein, the extent of inter-and intra molecular bonding (quaternary structure), and the environment (23).

CNP exhibits a higher content of minerals (10.9\%) than that of soy protein $(6.0 \%)$. The high mineral content of CNP is obviously due to presence of sodium, chloride which has been mixed with the solvent during the extraction of protein. In addition, CNP is higher in calcium and iron but lower in potassium, phosphorus and magnesium compared to soy protein. A high mineral content (ash content), especially sodium, may substantially affect the comparative functional properties of CNP and soy protein. The mineral components, are of importance as they influence the ionic strength and hence the attractive and repulsive forces between protein in solution (24).

Table 2 lists the amino acid composition of CNP in relationship to soy protein concentrate. The column for $(\mathrm{Xi}-\mathrm{Yi})^{2}$ shows the squared differences between the amino acid content for the two 
samples which is helpful for evaluating $\mathrm{S} \Delta \mathrm{Q}$ as a measure of the relatedness of the proteins (25). The test for relatedness based on the $\mathrm{S} \Delta \mathrm{Q}$ value very little similarity between the two entities. The disparity is possible due to a great difference in arginine content of CNP $(11.50 \%)$ over soy protein $(5.59 \%)$.

The unusually high amount of arginine would likely be a cause for a lack of similarity between CNP and soy protein. This diversity is pronounced by distinct differences in clectrophoretic patterns of the two types of proteins, as shown in Figure 3. These patterns support the concept that $\mathrm{CNP}$ and soy protein are inherently different. However, it may be noted that the ultracentrifuge patterns of coconut protein exhibit distinct similarity to soy protein (26). The dissimilarity in electrophoretic patterns reveals a variation in the protein composition of CNP and soy protein, which may give rise to different physical and functional characteristics between these entities. One of the effects; which might be anticipated for an increase in arginine content relates to an increase in hydrophilic properties. Waugh (27) and Fisher (28) have arbitrarily assumed that arginine possesses; a polar side chain and contributes to an increase of the hydrophilic regions of proteins, which is important in water binding.

The hydrophobicity values of CNP and soy protein measured by alkane binding and cis-parinaric acid are shown in Table 3. Higher effective-hydrophobicity values for CNP were observed in comparison to those of soy proteins. On the other hand, using the calculation method developed by Bigelow (9). CNP and soy protein exhibit similar hydrophobicity values (H Ø ave) of 974 and $979 \mathrm{cal} / \mathrm{res}$, respectively. The differences of the values determined by alkane binding, cis-parinaric acid and Bigelow's method are obviously related to the use of different methods used for hydrophobicity measurement.

In spite of the content of high in arginine which may increase, the hydrophilic regions of CNP, hydrophobicity measurements have demonstrated that CNP is more hydrophobic than the soy protein. The contradiction in this comparison reflects a need for further investigation of the relative importance of the hydrophobic and hydrophilic characteristics of CNP and soy protein.

The sulfhydryl and disulfide analyses revealed that CNP has a lower content of sulfur amino acids compared to soy protein (Table 4). This result is in agreement with the finding reported by Gonzales and Tanchuco (29). Different values of their sulfhydryl (SH) and disulfide (SS) contents. May contribute to cdifferences in chemical properties between CNP and soy protein. The SH and SS groups have been considered as important functional groups in many food proteins, such as in a complex formation between B-lactoglobulin and K-casein when milk was heated (30). Thus SH and SS groups provide significant effects to, food systems and the variation in SH and SS group content may contribute to different functionalities between CNP and soy protein.

The electrophoretic patterns of unfractionated protein from fresh coconut, CNR and soy protein concentrate are presented Figure 3. The molecular weights of the major bands are listed in Table 5. In general, the electrophoretic analysis of protein from fresh coconuts and CNP show a molecular weight range of monomer units from 20,000 - 55,000. There is a lack of correspondence between the assigned molecular weight for the major protein bands in the unseparated protein from fresh coconut and the major bands in the CNP. The protein from, fresh coconut consist of a monomer unit 29,000 Daltons, while CNP exhibits a monomer unit of 26,000. This divergence might be due to the effect of heat during the preparation of DCN. Soy protein reveals heterogeneous units with a molecular weight range from, 20,000 - 70,000. It may be noted that the electrophoretic patterns of soy protein is distinctly different from unfractionated proteins of fresh coconut and CNP.

In the above study, CNP has been compared with soy protein in terms of their composition id chemical properties. The amino acids composition of CNP is different from that of soy protein concentrate. Additionally, several differences have been found in physical and chemical properties of $\mathrm{CNP}$ and soy protein. The importance of composition and chemical properties of proteins have been 
reviewed in many reports; however, in order to be valuable and applicable in prepared foods, the protein should possess several desirable characteristics referred to as functional properties (18). Therefore, the physical and functional properties of CNP and soy protein will be discussed in the following section.

\section{PHYSICAL AND FUNCTIONAL PROPERTIES}

\section{BULK DENSITY}

The bulk density value, Of CNP and soy protein are $0.18 \mathrm{~g} / \mathrm{ml}$ and $0.41 \mathrm{~g} / \mathrm{ml}$, respectively. Soy protein reveals considerably higher bulk density value than that of CNP density may be an important property in terms of water binding and lipid absorption because bulk density reflects the state of subdivision and the surface to volume ratio of the particles. The difference in bulk density values between CNP and soy protein may contribute to differences in behavior of these proteins in food systems.

\section{SOLUBILITY}

Solubility reflects the amount of protein in a sample that dissolves and disperses thoroughly. The measured values for the solubility index of CNP and soy protein were analyzed using multiple regressions and were derived in the following models (1) and (2) for protein solubility of CNP and soy protein, respectively:

$$
\begin{aligned}
& \text { Sol }=15.3-0.58 \mathrm{~T}+0.14 \mathrm{~T} \times \mathrm{pH} ; \mathrm{R}^{2}=0.97 \\
& \text { Sol }=-381.2+113.9 \mathrm{pH}+0.02 \mathrm{~T} \times \mathrm{pH}-7.369 \mathrm{pH}^{2} ; \mathrm{R}^{2}=0.99
\end{aligned}
$$

Where: Sol $=$ protein solubility $(\%)$ and

$$
\mathrm{T}=\text { temperature }\left({ }^{\mathrm{O}} \mathrm{C}\right)
$$

All of the variables contained in the empirical equations were significant at $p<0.01$. The form of the two equations suggests that these two proteins behave quite differently with regard to solubility. The correlation coefficients between the predicted and measured values for the solubility of CNP and soy protein are shown in Table 6. It may be noticed that the values of the correlation coefficients for the regression model (RM), $\mathrm{R}^{2}$, are identical to the $\mathrm{RP}^{2}$ for goodness of fit (GF). The $\mathrm{R}^{2}$ values are close to 1.0 indicating that the predicted values are in good agreement with the measured values.

Using the empirical equations, three dimensional plots of protein solubility as a function of $\mathrm{pH}$ and temperatures are illustrated in Figure 4 and 5 for CNP and soy protein, respectively. The influence of $\mathrm{pH}$ on soy protein is more obvious than for CNP and may possibly reflect a greater extent of denaturation during, the preparation of the CNP than of the soy protein. In general, the solubility indices of CNP were lower compared to those of soy protein, except at $\mathrm{pH}$ 5.0. The low solubility at $5 \mathrm{pH}$ shows the common response to $\mathrm{pH}$ in the vicinity of the isoelectric point. Protein solubility generally decreases as the $\mathrm{pH}$ approaches the isoelectric point. On the other hand, the effect of temperature on the solubility of CNP is nearly indistinguishable from that of soy protein. The relatively small response of temperature on the solubility of the two proteins reflects that the temperature range chosen $\left(30^{\circ} \mathrm{C}\right.$ and $\left.70^{\circ} \mathrm{C}\right)$ is still comparatively moderate and does not cause any large conformational change to protein structure. The temperature effects on the solubility obtained for soy protein are similar with the finding reported for soy protein concentrate and isolate (31).

Both $\mathrm{pH}$ and temperature are important factors; for the solubility of CNP and soy protein. In this study, CNP exhibits a lower solubility than that of soy protein. This is somewhat surprising because Rasyid et al. (26) have reported that coconut proteins extracted from fresh coconuts are quite 
soluble in aqueous or diluted salt solution. The difference in solubility may be due to the disparity of the amino acid composition between these two entities and, in particular. to the higher hydrophobicity value of CNP than that of soy protein. Rasyid (4) proposed that another possible reason for the difference in solubility is the content of carbohydrate, which is somewhat higher in soy protein (19\%) than in CNP (15\%). Carbohydrates are hydrophilic components and are able to absorb large quantities of water which become available for the protein, resulting in increasing the protein Solubility (31).

The low solubility of CNP may be a detriment for certain applications but may be less critical in other instances, such as in water binding or in fat absorption. Philips and Stemberg (32) reported that com protein concentrate exhibited low solubility but high water and fat absorption in comparison with soy protein concentrate. Moreover, Wingerd (33) and Robinson et al. (34) have reported that heated lactalbumin exhibits low solubility but displays good water binding characteristics. Therefore, the assumption that proteins must have a high initial solubility as a prerequisite for adequate functional behavior is not always true.

\section{WATER BINDING}

Water binding reflects the amount of water absorbed or retained by a solid system, such as protein and starch or their mixtures. The measured values for water binding of CNP and soy protein for the different combinations of $\mathrm{pH}$ and temperatures were analyzed using, multiple regressions and derived in the following models (3) and (4) for CNP and soy protein, respectively:

$$
\begin{aligned}
& \mathrm{WB}=3.08+0.05 \mathrm{~T}-0.007 \mathrm{~T} \times \mathrm{pH}+0.002 \mathrm{pH}^{3} \mathrm{R}^{2}=0.88 \\
& \mathrm{WB}=9.61+0.014 \mathrm{~T}-2.07 \mathrm{pH}+0.153 \mathrm{pH}^{2} \mathrm{R} 2=0.87
\end{aligned}
$$

Where: WB = water binding $\left(\mathrm{gH}_{2} \mathrm{O} / \mathrm{g}\right.$.sample $)$ and

$$
\mathrm{T}=\text { temperature }\left({ }^{\mathrm{O}} \mathrm{C}\right)
$$

The variables described in the empirical equations were significant $(\mathrm{p}<0.01)$. The correlation coefficients between the predicted and measured values for the water binding of CNP and soy protein are also shown in Table 6. Again, it may be noticed that the values of the correlation coefficients for the regression model (RM). $R^{2}$, are identical to The $R^{2}$ for goodness of fit (GF). The $R^{2}$ values are somewhat below 1.0 indicating that the predicted values are in poorer agreement with the measured values than was the case for solubility.

Figure 6 and 7 drawn using the empirical equations, show the three dimensional plots of water binding as a function of $\mathrm{pH}$ and temperature for $\mathrm{CNP}$ and soy protein, respectively. The water binding of CNP and soy protein was affected by $\mathrm{pH}$ and temperature. Overall and especially for soy protein, water binding capacities decreased as $\mathrm{pH}$ values approached neutral (6-7) and then increased as the $\mathrm{pH}$ approached 8 . Temperature affected positively the water binding capacities of these proteins. At various combinations of $\mathrm{pH}$ and temperatures, the CNP bound water was 3.6- $4.2 \mathrm{~g}$ $\mathrm{H}_{2} \mathrm{O} / \mathrm{g}$ dry sample, which was comparable to the water binding of soy protein $\left(3.2-4.2 \mathrm{~g} \mathrm{H}_{2} \mathrm{O} / \mathrm{g}\right.$ dry sample). These values resemble the data found for soy protein and sunflower concentrate and com germ protein $(35,36)$.

In general, the water binding of CNP was similar to that of soy protein. However, the solubility analysis revealed a lower solubility for CNP than for soy protein. The apparent contradiction between water binding, capacity and solubility suggests that these two parameters are not correlated. This observation is in agreement with the findings reported by Philips and Stemberg (32) where com protein exhibited a lower solubility but higher water binding compared to soy protein. Kinsella (37) reported that the $\mathrm{pH}$ of adqueous suspensions of proteins had little effect on water absorption, again indicating an absence of a correlation between water binding and protein 
solubility. Furthermore, it is known that some hydrocolloids, such as microcrystalline cellulose, are insoluble, yet, demonstrate a high water binding capacity.

The relatively light water binding, capacity of CNP may be related to properties associated with its bulk density. Low bulk density is usually associated with fine particle size which reflects a high surface to volume ratio of the particles. In this case, the high water absorption results from the large surface available for contact. This result is in agreement with the data reported by Wang and Kinsella (18). They reported that alfalfa leaf protein with low bulk density values exhibits high water binding and vice versa. Moreover, particle size and particle size distribution are often important factors which may affect water and fat absorption in a given application (38). In this study, the preparation of CNP powder involved freeze drying under conditions which produced a porous/filamentous product with a large surface.

The small response of temperature on the water binding of CNP and soy protein may possibly be due to a compensating, influence of other components, such as starch. For example, increasing the temperature of a starch-containing product will cause the starch to swell and spontaneously increase the uptake of water. The water binding capacity of different proteins may be expected to vary with protein source composition, $\mathrm{pH}$, and the presence of carbohydrates, lipids, and salts, as well as affected by previous processing methods $(17,24,35,40)$.

\section{LIPED ABSORPTION}

Fat or lipid absorption may be defined as the percentage of fat bound by protein after thorough mixing and centrifuging, and is affected by the hydrophobicity of the protein. The measured values for the lipid absorption of CNP and soy protein for all possible combinations of concentration and temperature were derived using multiple regression analysis:

$$
\begin{aligned}
& \mathrm{LA}=1.85+0.006 \mathrm{~T}+0.051 \mathrm{C} \quad \mathrm{R}^{2}=0.92(\mathrm{p}<0.01) \\
& \mathrm{LA}=1.68-0.023 \mathrm{~T}+0.0002 \mathrm{~T} \times \mathrm{C}+0.0003 \mathrm{~T}^{2} \\
& \mathrm{R}^{2}=0.94(\mathrm{p}<0.01)
\end{aligned}
$$

Where: $\mathrm{LA}=$ lipid absorption, $\mathrm{T}=$ temperature $\left({ }^{\mathrm{O}} \mathrm{C}\right)$, and $\mathrm{C}=$ concentration $(\%)$.

All of the variables contained in the empirical equations were significant at $\mathrm{P}<0.01$. The correlation coefficients between the predicted and measured values for the lipid absorption of CNP and soy protein are shown in Table 6. Again, it may be noticed that the values of the correlation coefficients for the regression model (RM), R2, are identical to, the $\mathrm{R}^{2}$ for goodness of fit (GR The $\mathrm{R}^{2}$ values of CNP and soy protein are close to 1.0 indicating, that the predicted values are in good, agreement with the measured values.

The effects of concentration and temperatures on the lipid absorption (g oil/g sample) of CNP (Figure 8) and soy protein (Figure 9) are graphically illustrated using the empirical equations. Over all, the amount of oil bound per unit weight of protein was relative constant. Both concentration and temperatures reveal little effect on the lipid absorption of CNP and soy protein. This lack of response may be due to the use of a relatively low or moderate temperature which may not have provided enough energy to expose hydrophobic amino acids. However, an increase of temperature to $70^{\circ} \mathrm{C}$ increases the lipid absorption of soy protein. CNP exhibits higher lipid absorption ability (2.2 $3.0 \mathrm{~g}$ oil $/ \mathrm{g}$ sample) compared to soy protein (1.2 - $1.7 \mathrm{~g}$ oil $/ \mathrm{g}$ sample). Scopes (41) stated that hydrophobic amino acids are normally concentrated within the interior of die protein molecules. Hence, if there is almost no conformational change of die protein structure occurring during heating no additional exposed hydrophobic side groups will become available to affect lipid absorption. 
Kinsella (37) has reported that fat binding capacity may be attributed to a physical entrapment of fat in the protein matrix and that bulk density is an important consideration. In terms of alfalfa leaf protein, a variation of the bulk density to about $2-3$ fold over the controls resulted in decreasing the fat absorption, capacity by $50 \%(18)$.

\section{SENSORY EVALUATION}

The flavor analysis showed that the control and samples with 30 and $46 \%$ added CNP differed from the other samples and the results were significant at the $5 \%$ level. The control was the least preferred product in terms of flavor, whereas samples with, 30 and $40 \%$ added CNP were most, preferred. It was apparent that the panelists preferred samples with fortified CNP (30 and $40 \%$ ) to the control.

In contrast, flavor analysis performed on crackers with added soy protein showed that all of the fortified samples differed from the control and the results are significant at the $5 \%$ level. The panelists recognized the presence of an objectionable flavor at concentrations of soy protein as low as $10 \%$. The overall analyses of flavor in this study have demonstrated that the panelists preferred crackers with added CNP to that of soy protein. Apparently, soy protein contributes beany, bitter, astringent and other flavors to, the crackers (42).

The textural analysis for CNP showed that the control differed from the samples and the results are significant at the $5 \%$ level from the other samples. No further differences among other samples were detected. In this case, the control was the least preferred product. For the samples fortified with soy protein the texture analysis failed to show any differences.

In terms of texture, most panelists commented that CNP-crackers were more crispy than soy-protein crackers. Crispiness is an important sensory attribute that relates to textural characteristics of fresh dry cereal and starch-based snack food products. Katz and Labuza (43) have reported that a major cause of snack food rejection by consumers is loss of crispiness due to, the absorption of moisture.

Differences in textural scores between the two types of crackers may be due to the difference in carbohydrate content between CNP (14.6\%) and soy protein $(19.2 \%)$. The high carbohydrate content in soy protein may be a cause for increased hygroscopicity and greater absorption of water which may be detrimental to the crispiness of the tested crackers. Katz and Labuza (43) have stated that water affects the texture of dry snack foods by plasticizing, and softening the starch-protein matrix, which changes the mechanical strength of the products. For example, the potato chip industry considers chips with more than $3 \%$ moisture as unsalable and in the United King Dom crackers are unacceptable 8 when the moisture content exceeds $3.5 \%$.

In conclusion, the overall results of this study demonstrated that CNP possessed comparable compositional and chemical properties to the reference soy protein with the exception of a high sodium content. A test for relatedness among proteins $(\mathrm{S} \Delta \mathrm{Q})$ showed very little similarity between the amino acid profiles of the two protein entities. Moderate difference was observed between the hydrophobicity values as well as for the sulfhydryl and disulfide group's contents of these proteins. The disparity was reflected in dissimilarity in the electrophoretic patterns between CNP and soy protein. CNP exhibited a lower solubility but higher lipid absorption capacity than soy protein. The water binding capacity was the same for the two proteins. Sensory analysis revealed that panelists preferred crackers with added CNP over crackers with added soy protein. The overall results of this study suggest a potential use of CNP as an alternative protein source to soy protein for use in manufactured foods where solubility is not a critical factor. 


\section{REFERENCES}

1. The World Bank. 1991 World Bank technical paper. No. 136. Washington D.C.

2. Woodroof, J.G. 1979 Coconuts: Production, Processing, and Products, 2nd Ed. p. 8-10. AVI Publishing Company, Inc., Westport, CT.

3. Food and Agriculture Organizations of The United Nations (1990) FAO yearbook, Production, 44: 170 .

4. Rasyid, F. 1992. Ph.D. dissertation. The Ohio State University. Columbus, Ohio.

5. Association of Official Analytical Chemist (AOAC) 1990 Official Methods of the Association of Official Analytical Chemist. 5th Ed. AOAC, Inc. Arlington, Virginia.

6. Mohammadzadeh-k, A., Feeney, R. E., Samuels, R. B. and Smith, L. M. 1967 Biochim. Biophys. Acta. 147:583

7. Mangino, M. E., Fritsch, D. A., Liao, S. Y., Fayerman, A. M., and Harper, W. J. 1985 N. Z. J. Dairy Sci. and Tech. 20:103-107.

8. Kato, A. and Nakai, S. 1980 Biochim. Biophys. Acta. 576:269.

9. Bigelow, C. 1967. J. Tlireoret. Biol. 16:187-211.

10. Bevefidge, T., Toma, S. J., and Nakai, S. 1874 J. Food Sci. 39:49-5 1.

11. Laemmli, U. K. 1970 Nature (London), 227:680.

12. Wilkinson, L. 1989a Systat: The System for Statistics SYSTAT. Inc. Evanston, Illinois.

13. Wilkinson L. 1989b Sygraph: The System for Graphics. SYSTAT. Inc. Evanston, Illinois.

14. Voutsinas, L. P. Cheung. E., and Nakd. S. 1983 1. Food ci. 48:26-32.

15. Bearden, J. M. 1978 Arch Biochem. Biophys. 533: 525-529.

16. Aguilera, J. M. and Kosikowski, F. V. 1978 J. Dairy Sci. 61(11):1548-1556.

17. Lin, M. J. Y., Humbert, E. S., and Sosulski, E. S. J. Food Sci. 41:286-292.

18. Wang, J. C. and Kinsela, J. E. 1976 J. Food Sci. 41:286-292.

19. Kramer, A. 1956 Food Technol. 10:391-392.

20. Kinsella, J. E. 1982. In Food Proteins; Fox, P. and Condon, 1., Eds.; Applied Science Publishers. New York. p. 51-103.

21. Mangino, M. E. 1984 J. Dairy Sci. 67:2711-2722

22. Moff, C.V. 1990 J. Am. Oil Chem. Soc.67(5):265-271

23. Kinsella, J. E. 1979. Functional properties of soy proteins. J. Am. Oil Chem. Soc. 56(3) : $242-258$.

24. Hennansson, A. M. and Ak-esson, C. 1975 J. Food Sci. 40:595-602.

25. Marehalonis, J. and Weltman, J. K. 1971 Comp. Biochem, Physiol. 38B:609.

26. Rasyid, F., Manullang, M., and Hansen, P.M.T. 1992 Food Hydrocolloids 6(3):301-414.

27. Waugh, D. F. 1954 Adv. Protein Chem. 9:325-437.

28. Fisher, H. F. 1964 Proc. Natn. Acad. Sci. Wash. 51:1285-1291.

29. Gonzalez, O. N. and Tanchuco, R. H. 1977 Phil. J. Coco. Studies 11(3):21-30.

30. Sawyer, W. H. 1969 J. Dairy Sci. 52:1347-1355. 
31. Hutton, C. W. and Camphell. A. M. 1977. Functional properfies of a soy concentrate and a soy isolate in simple systems. Nitrogen solubility index and water absorption. J. Food Sci. 42:454456.

32. Philips, R. D. and Stemberg, M. (1979) J. Food Sci. 44:1152-1161.

33. Winggerd, W. H. 1971 J. Dairy Sci. 54:1234-1236.

34. Robinson, B. P., Short, J. L. and Marshall, K. R. 1976 N. Z. J. Dairy Sci. Technol. 11: 114-118.

35. Fleming, S. E., Sosulski, F. W., Kilara, A., and Humbert, E. S. 1974 J. Food Sci. 39:188-191.

36. Hung, S. C. and Zayas, J. F. 1992 J. Food Sci. 57:372-376.

37. Kinsella, J. E. 1976 CRC Crit. Rev. Food Sci. Nutr. 7:219-280.

38. Johnson, D. W. 1970 J. Am. Oii Chem. Soc. 47(10):402-407.

39. Hagenmaier, R. 1972 J. Food Sci. 37:965-966.

40. Scopes,R.K.1987 Protein Purification: Principles and Practices. $2^{\text {nd }}$ Ed. Springer-Verlag. New York Inc.

41. Pomeranz, Y. 1991 Functional Properties of Food Components. $2^{\text {nd }}$ Ed. Academic Press Inc. San Diego, Califomia.

42. Katz, E. E. and Labuza, T. P. 1981 J. Food Sci. 48:403.409.

Table I

Chemical compositions of CNP and soy protein

\begin{tabular}{|l|c|c|}
\hline \multicolumn{1}{|c|}{ Composition (g/100g) } & CNP & Soy Protein (Central Soya) \\
\hline Protein & $64.5+0.1$ & $68.0(\mathrm{a})$ \\
Fat & $1.1+0.1$ & $0.8(\mathrm{a})$ \\
Moisture & $8.9 \pm 0.1$ & $6.0(\mathrm{a})$ \\
Carbohydrate (b) & $14.6 \pm 0.1$ & $19.2(\mathrm{a})$ \\
Ash & $10.9 \pm 0.1$ & $6.0(\mathrm{a})$ \\
Minerals (mg/100g) & & \\
Sodium & $4,731.6 \pm 165.7$ & $50.0 \pm 2.9$ \\
Potassium & $121.7 \pm 6.1$ & $2,400.0 \pm 52.7$ \\
Calcium & $480.0 \pm 17.7$ & $420.0 \pm 6.6$ \\
Iron & $17.7 \pm 1.4$ & $12.0 \pm 0.2$ \\
Phosphorus & $334.8 \pm 7.8$ & $910.0 \pm 1.3$ \\
Magnesium & $188.6 \pm 7.9$ & $320.0 \pm 4.9$ \\
Zinc & $58.3 \pm 2.0$ & $6.0 \pm 0.1$ \\
Copper & $5.2 \pm 0.1$ & $1.5 \pm 0.1$ \\
\hline
\end{tabular}

(a) Data obtained from CENTRAL SOYA, Chemurgy Division.

(b) By difference 
Table 2

Amino acid analysis of CNP and soy protein concentrates

\begin{tabular}{|l|c|c|c|}
\hline \multicolumn{1}{|c|}{ Amino Acid } & CNP (X) (Mol \%) & Soy Protein (Y) (Mol \%) & $\mathbf{( X i - Y i ) ~}^{\mathbf{2}}$ \\
\hline Alanine & $7.22 \pm 0.09$ & $6.62 \pm 0.03$ & 0.36 \\
Arginine & $11.50 \pm 0.09$ & $5.59 \pm 0.18$ & 34.93 \\
Asparic acid & $9.35 \pm 0.01$ & $11.87 \pm 0.07$ & 6.35 \\
Glutamic acid & $15.96 \pm 0.11$ & $17.29 \pm 0.05$ & 1.77 \\
Glycine & $8.67 \pm 0.18$ & $7.72 \pm 0.09$ & 0.90 \\
Histidine & $1.39 \pm 0.17$ & $1.89 \pm 0.02$ & 0.25 \\
Isoleucine & $4.63 \pm 0.01$ & $5.18 \pm 0.09$ & 0.30 \\
Leucine & $7.79 \pm 0.33$ & $8.07 \pm 0.00$ & 0.08 \\
Lysine & $3.42 \pm 0.02$ & $5.81 \pm 0.08$ & 5.66 \\
Methionine & $1.52 \pm 0.39$ & $0.87 \pm 0.02$ & 0.42 \\
Phenylalanine & $4.16 \pm 0.01$ & $4.15 \pm 0.01$ & 0.00 \\
Proline & $4.37 \pm 0.01$ & $6.10 \pm 0.06$ & 2.99 \\
Serine & $6.45 \pm 0.06$ & $6.03 \pm 0.08$ & 0.18 \\
Theonine & $4.32 \pm 0.16$ & $4.36 \pm 0.09$ & 0.01 \\
Tyrosine & $1.69 \pm 0.04$ & $2.33 \pm 0.50$ & 0.41 \\
Valine & $7.60 \pm 0.12$ & $6.11 \pm 0.06$ & 2.22 \\
\hline
\end{tabular}

Value for protein relatedness, $\left[\mathrm{S} \Delta \mathrm{Q}=\left[(\mathrm{Xi}-\mathrm{Yi})^{2}\right]: 56.83\right.$

Table 3

Hydrophobicity values of CNP and soy protein determined by heptane binding, cis-parinaric acid, and Bigelow's method.

\begin{tabular}{|l|c|c|c|}
\hline \multicolumn{1}{|c|}{ Samples } & $\begin{array}{c}\text { Alkane Bound } \\
\text { (mg/g protein) }\end{array}$ & CPA (So) & Hoave (cal/res) \\
\hline CNP & $12.0 \pm 0.4$ & $2,726.7 \pm 19.5$ & $974 \pm 7$ \\
\hline Soy Protein & $7.8 \pm 0.5$ & $1,268.8 \pm 37.1$ & $979 \pm 8$ \\
\hline
\end{tabular}

Table 4

Sulfhydryl and disulfide values of CNP and soy protein

\begin{tabular}{|l|c|c|}
\hline \multicolumn{1}{|c|}{ Samples } & SH (M/g) & SS (M/g) \\
\hline CNP & $10.97 \pm 0.43$ & $31.71 \pm 0.29$ \\
\hline Soy Protein & $11.98 \pm 0.11$ & $34.90 \pm 0.52$ \\
\hline
\end{tabular}


Table 5

The molecular weight of the major electrophoretic bands of protein samples (a).

\begin{tabular}{|cc|c|}
\hline Protein samples (major bands) & & Molecular weight (Daltons) \\
\hline Unfractioned protein from fresh coconut & $\# 1$ & 21,754 \\
& $\# 2$ & 29,162 \\
& $\# 3$ & 54,873 \\
Coconut protein (CNP) & $\# 1$ & \\
& $\# 2$ & 20,717 \\
& $\# 3$ & 26,448 \\
Soy protein concentrate & & 54,873 \\
& $\# 1$ & \\
& $\# 2$ & 20,717 \\
& $\# 3$ & 23,986 \\
& $\# 4$ & 37,230 \\
& $\# 5$ & 43,106 \\
& $\# 6$ & 52,257 \\
\hline
\end{tabular}

(a) See Figure 3

Table 6

The correlation coefficients of regression model (RM) and goodness of fit (GF) for solubility, water binding and lipid absorption properties of CNP and soy protein.

\begin{tabular}{|l|l|l|l|l|}
\hline \multirow{2}{*}{ Properties } & \multicolumn{2}{|c|}{ CNP } & \multicolumn{2}{c|}{ Soy protein } \\
\cline { 2 - 5 } & RM & GF & RM & GF \\
\hline Solubility & 0.97 & 0.97 & 0.99 & 0.99 \\
Water binding & 0.88 & 0.88 & 0.87 & 0.87 \\
Lipid absorption & 0.92 & 0.92 & 0.94 & 0.94 \\
\hline
\end{tabular}


Figure 1. Preparation of coconut milk from desiccated coconut

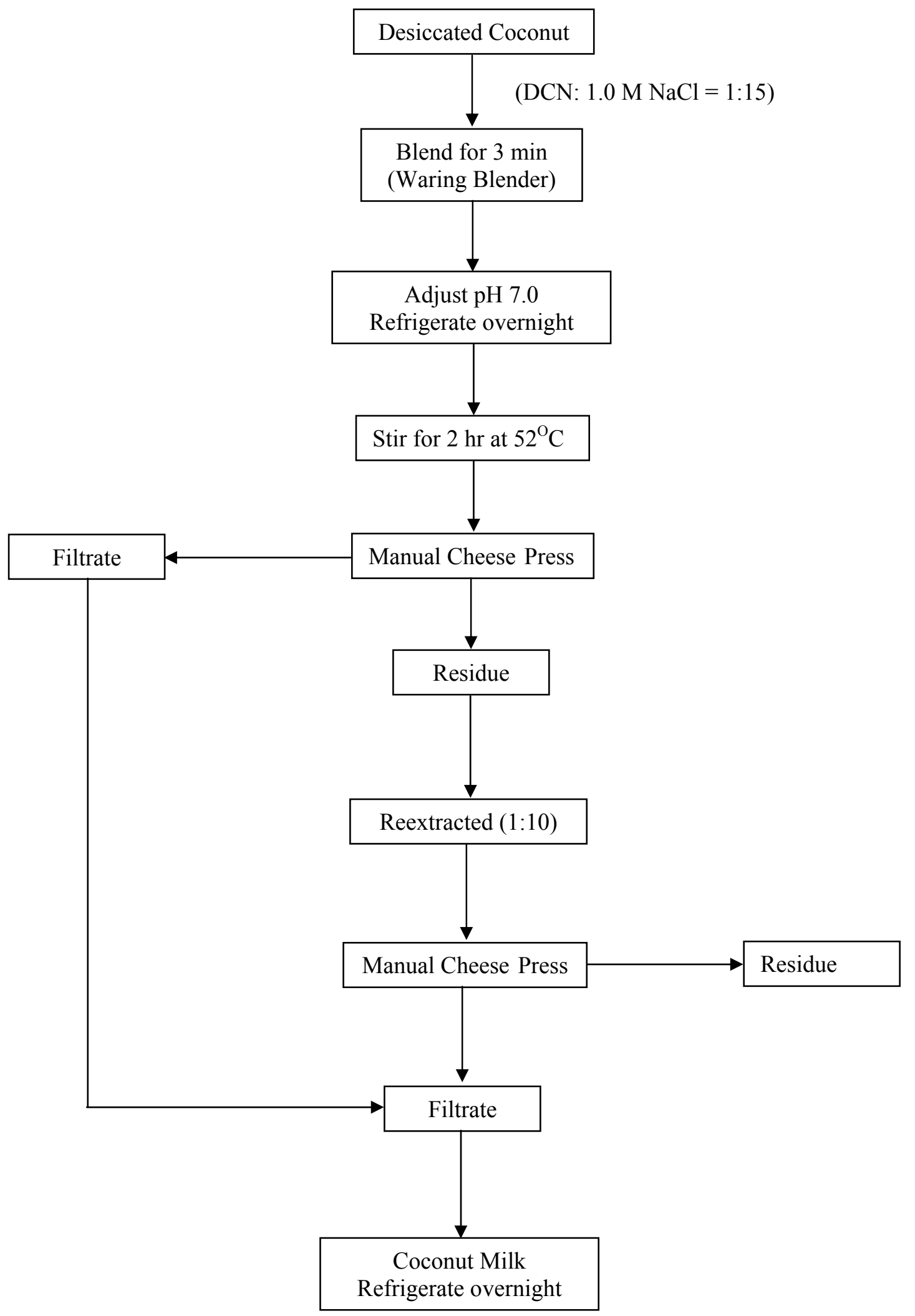


Figure 2. Preparation of CNP from coconut milk

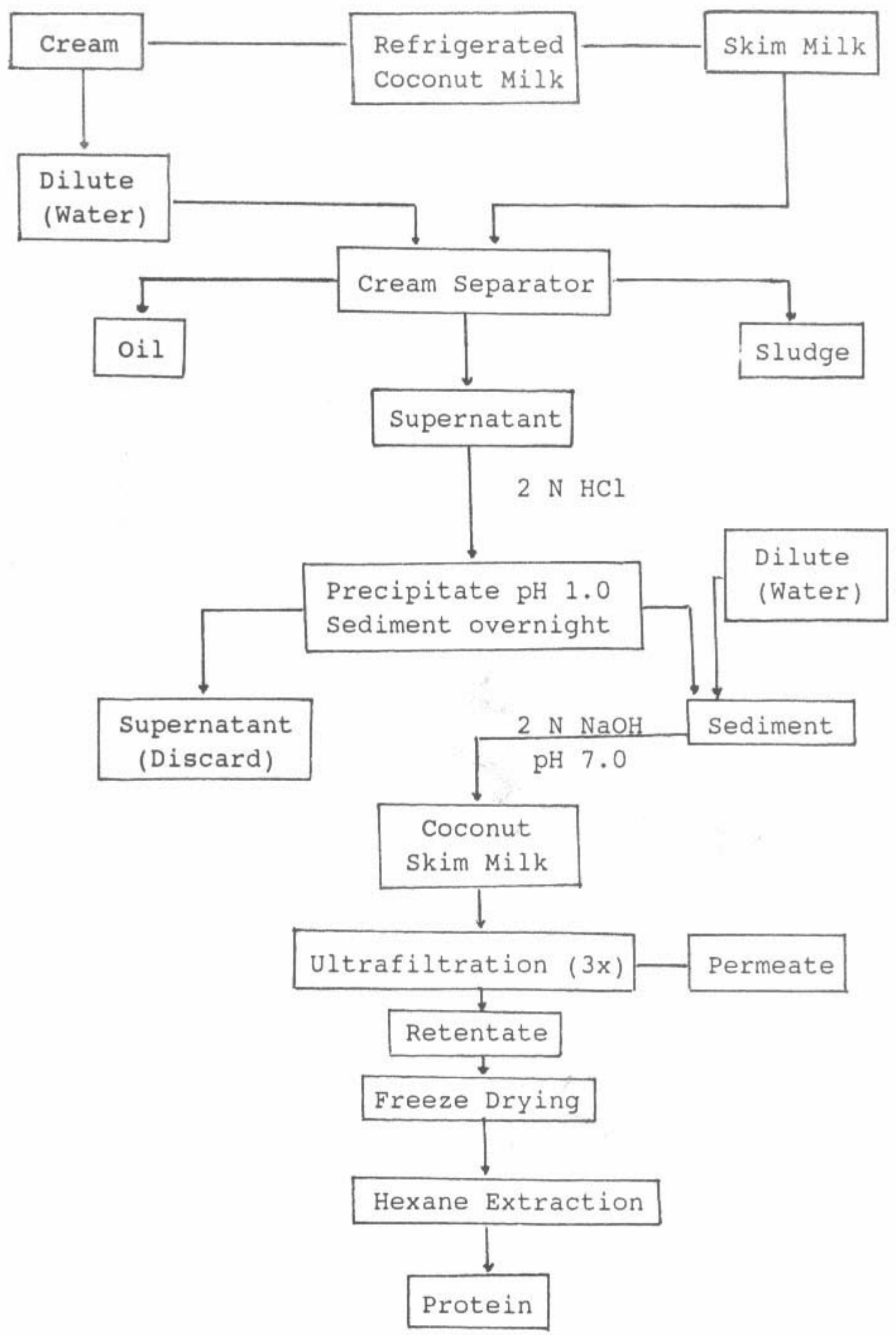




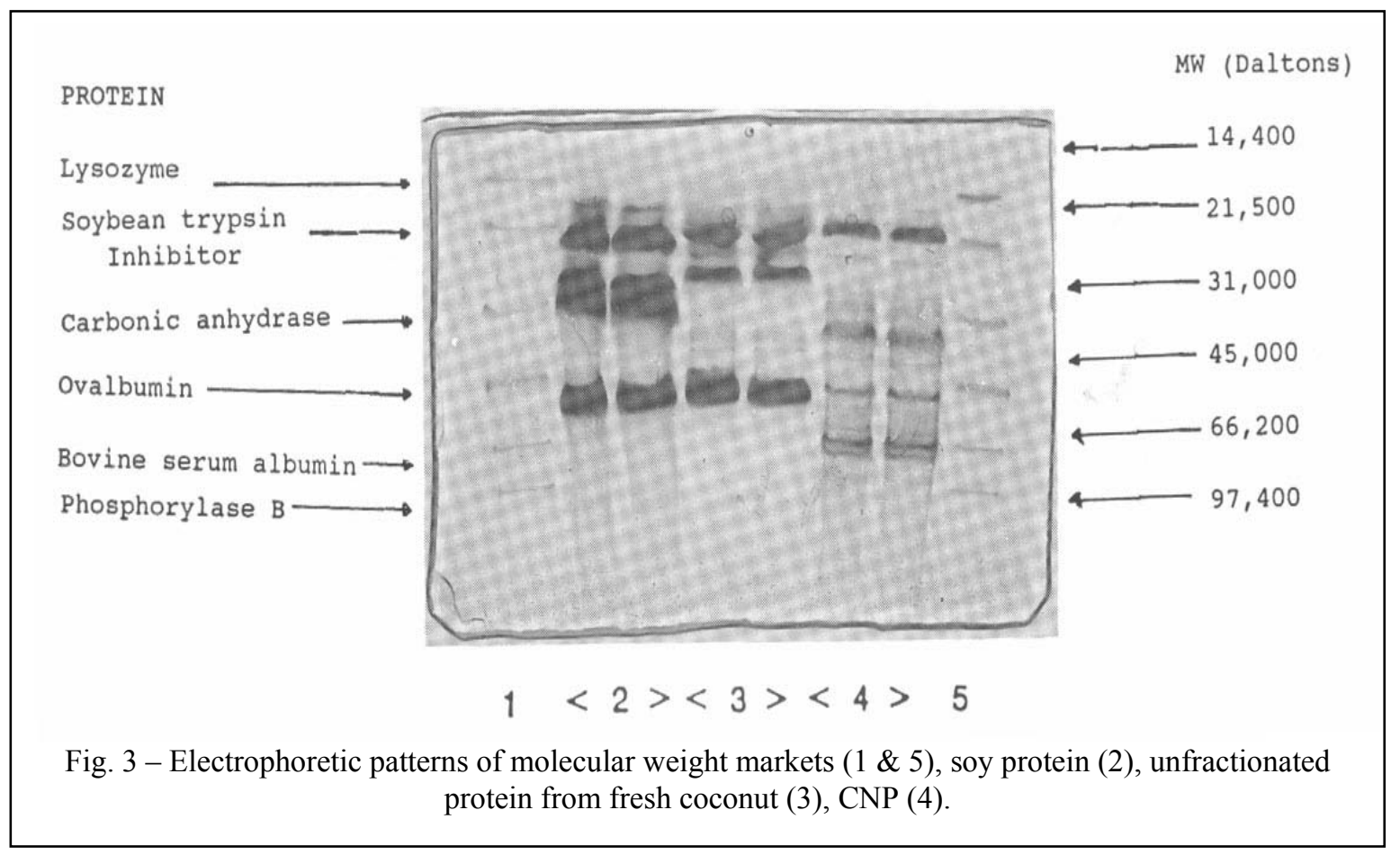




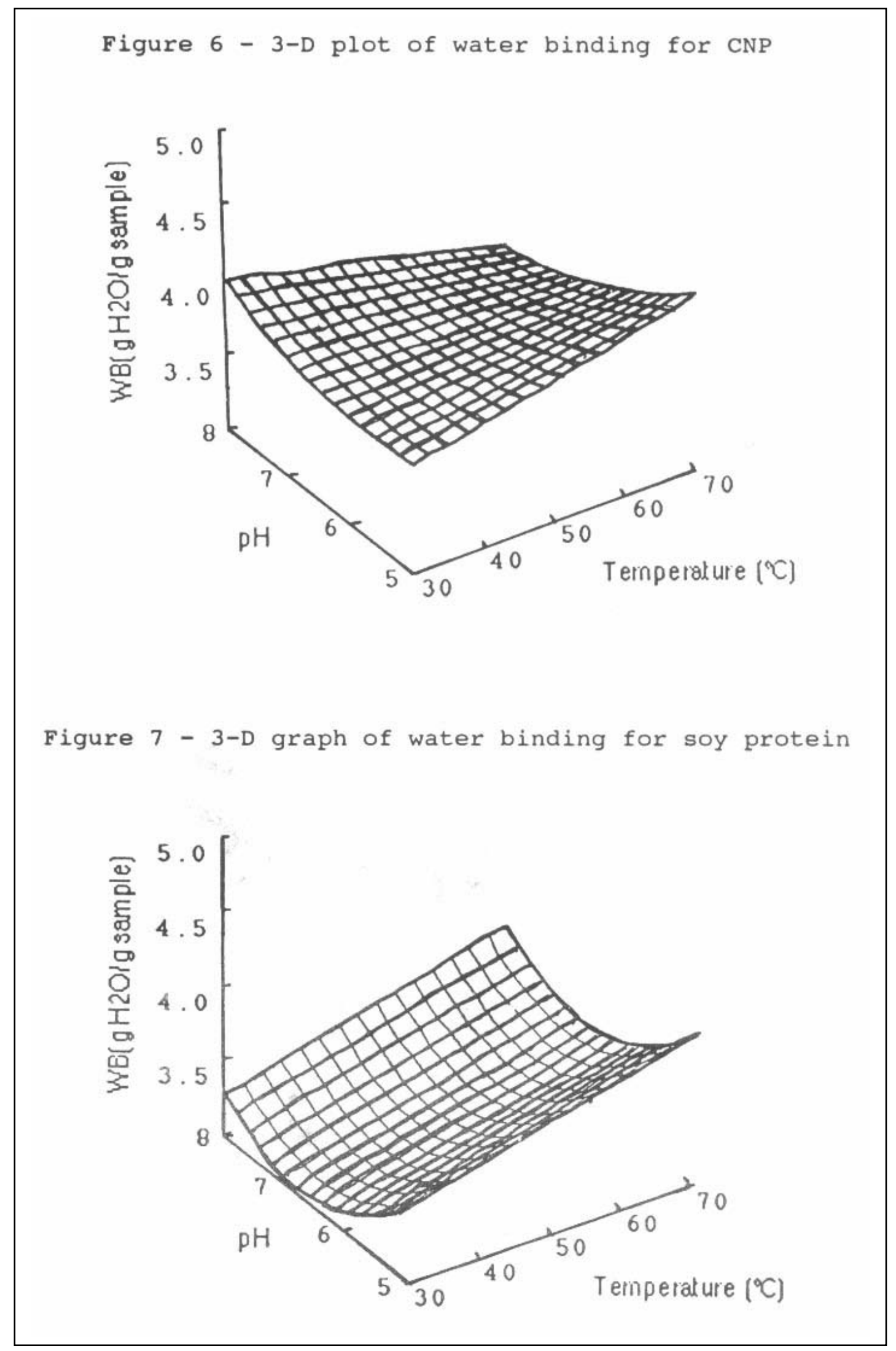


Figure 8 - 3-D plot of lipid absorption for CNP

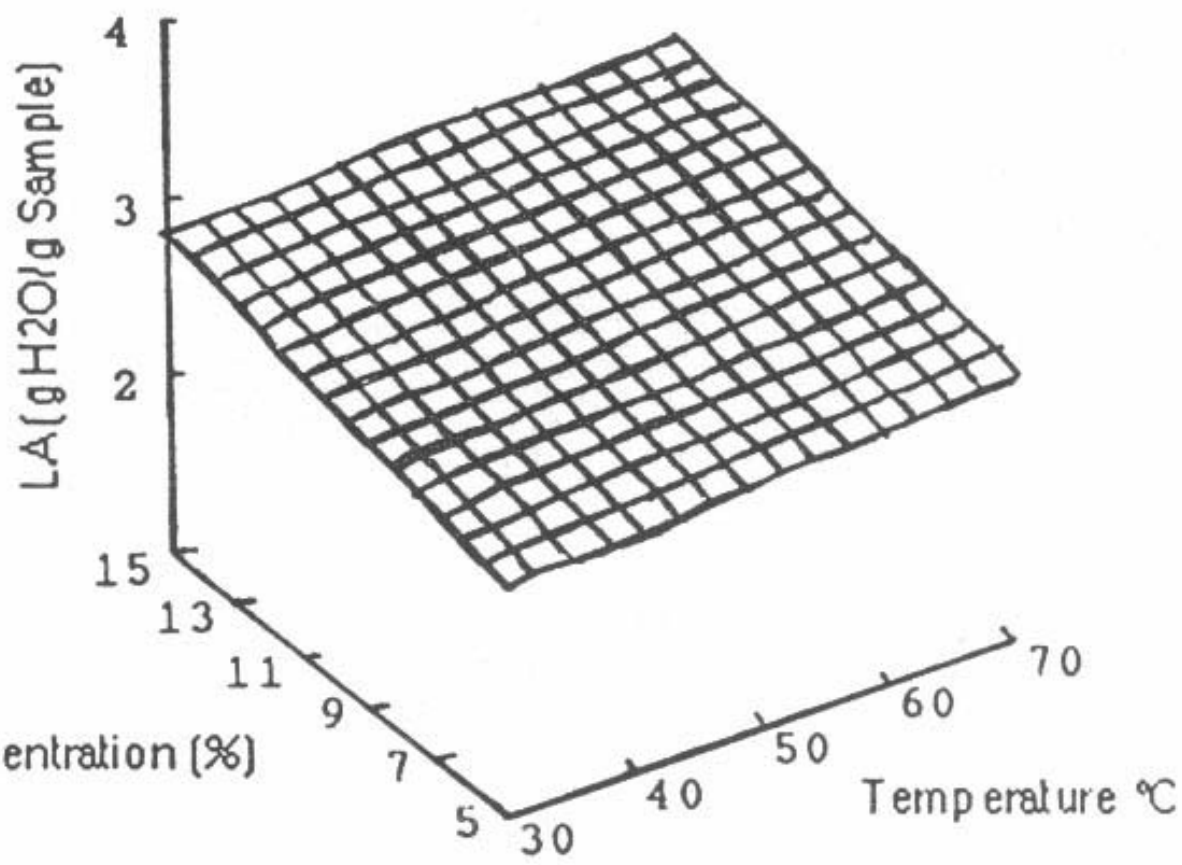

Figure 9 - 3-D plot of lipid absorption for CNP

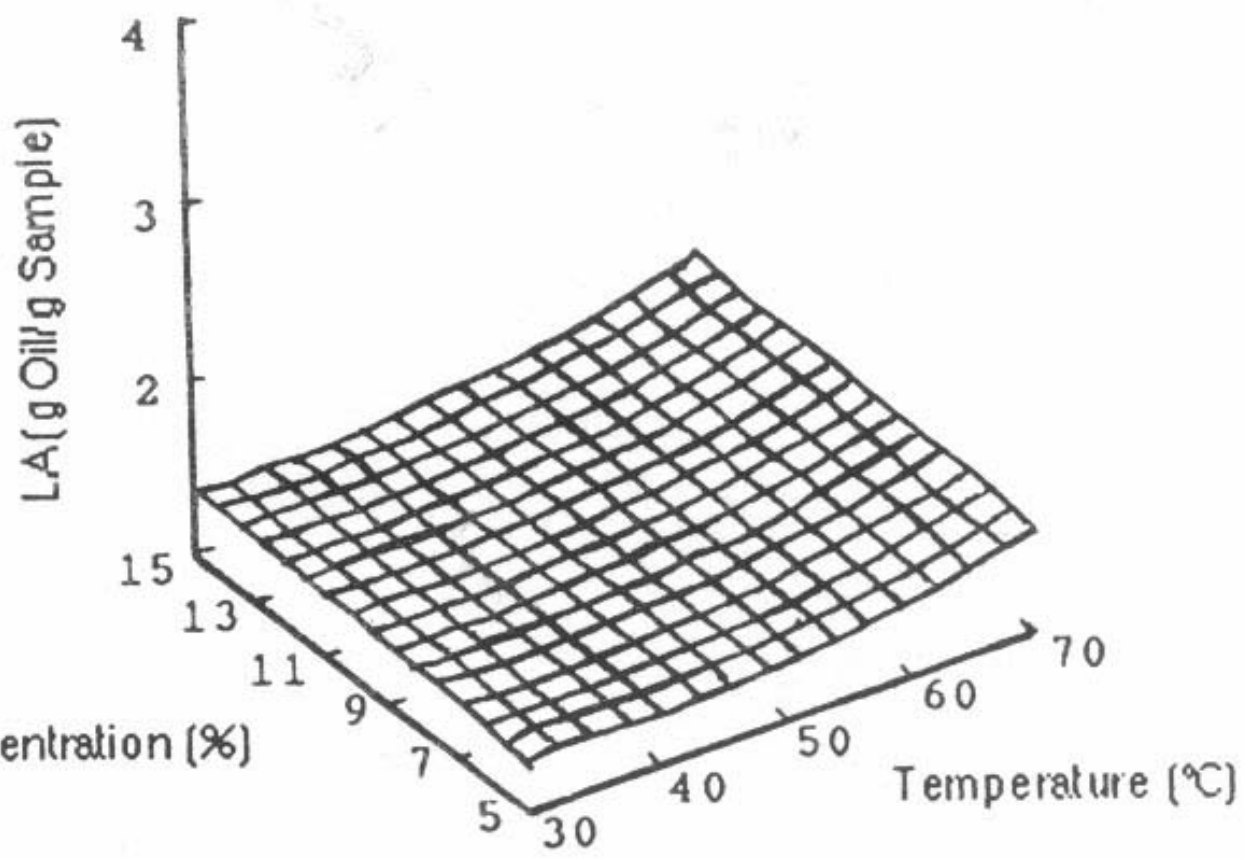


Figure 4 - 3-D plot of protein solubility for CNP

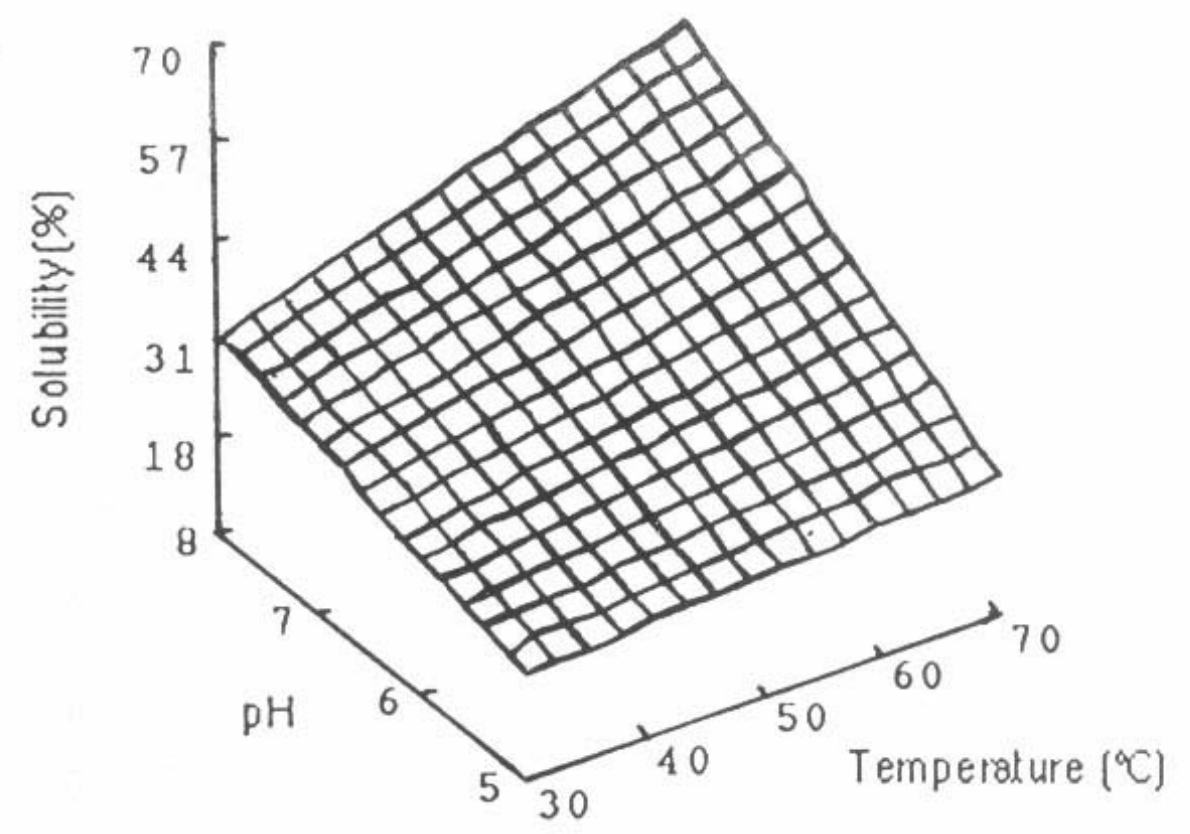

Figure 5 - 3-D plot of protein solubility for soy protein

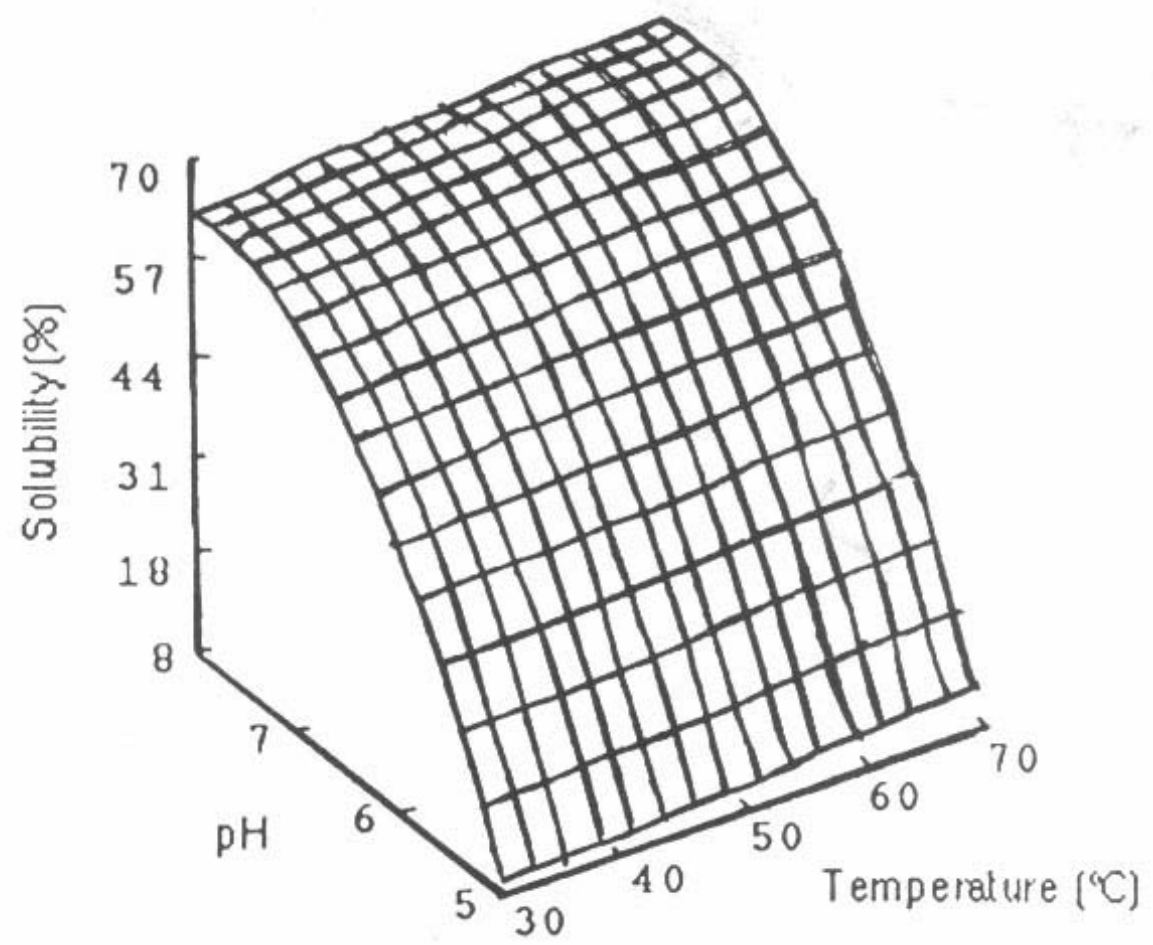

